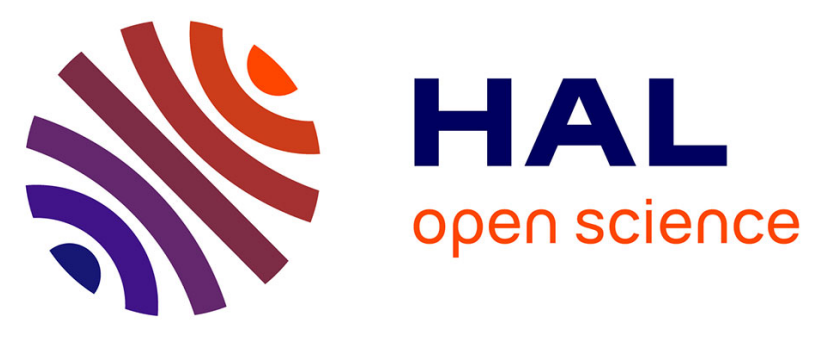

\title{
The Value of Legume Foods as a Dietary Source of Phytoprostanes and Phytofurans Is Dependent on Species, Variety, and Growing Conditions
}

María García-garcía, Mercedes del Río Celestino, Ángel Gil-izquierdo, Catalina Egea-gilabert, Jean-Marie Galano, Thierry Durand, Camille Oger, Juan Fernández, Federico Ferreres, Raúl Domínguez-perles

\section{To cite this version:}

María García-garcía, Mercedes del Río Celestino, Ángel Gil-izquierdo, Catalina Egea-gilabert, JeanMarie Galano, et al.. The Value of Legume Foods as a Dietary Source of Phytoprostanes and Phytofurans Is Dependent on Species, Variety, and Growing Conditions. European Journal of Lipid Science and Technology, 2019, 121 (8), pp.1800484. 10.1002/ejlt.201800484 · hal-02617139

\section{HAL Id: hal-02617139 \\ https://hal.science/hal-02617139}

Submitted on 3 Jun 2021

HAL is a multi-disciplinary open access archive for the deposit and dissemination of scientific research documents, whether they are published or not. The documents may come from teaching and research institutions in France or abroad, or from public or private research centers.
L'archive ouverte pluridisciplinaire HAL, est destinée au dépôt et à la diffusion de documents scientifiques de niveau recherche, publiés ou non, émanant des établissements d'enseignement et de recherche français ou étrangers, des laboratoires publics ou privés. 


\title{
The Value of Legume Foods as a Dietary Source of Phytoprostanes and Phytofurans Is Dependent on Species, Variety, and Growing Conditions
}

\author{
María C. García-García, Mercedes del Río Celestino, Ángel Gil-Izquierdo,* \\ Catalina Egea-Gilabert, Jean M. Galano, Thierry Durand, Camille Oger, \\ Juan A. Fernández, Federico Ferreres, and Raúl Domínguez-Perles
}

Bioactive phytoprostanes and phytofurans are synthesized in higher plants by nonenzymatic oxidation of a-linolenic acid (C18:3 n-3), triggered by high concentrations of reactive oxygen species. In the current scenario of changing dietary patterns, additional information is needed on the concentrations of oxylipins in legumes and on the effect of sustained deficit irrigation on their concentration. The main objective of the work is to elucidate the phytoprostane and phytofuran profile (including eight and three compounds, respectively) of three Pisum sativum cultivars ("mangetout" (ssp. arvense), "BGE-033620," and "Lincoln") and Phaseolus vulgaris (French bean cv. "Helda"), to unravel the oxidative response of these crops to sustained irrigation deficit in terms of oxidative stress, as well as in their importance as healthy dietary sources of new bioactive compounds. Phytoprostanes and phytofurans vary between varieties and species, with $9-\mathrm{F}_{1 \mathrm{t}}-\mathrm{PhytoP}$ and ent-16-(RS)13-epi-ST- $\Delta^{14}$-9-PhytoF being the most abundant. The level of phytoprostanes and phytofurans is also determined in sustained deficit irrigation ( $50 \%$ water needed), revealing modifications of their profile and concentration. In conclusion, bioactive phytoprostanes and phytofurans are present in legumes in high concentrations, being further modified by abiotic stress growing conditions, highlighting the importance of this plant food as a dietary source of these bioactive molecules. Practical Applications: This work is of high relevance from the lipidomic point of view, given that phytoprostanes and phytofurans have been promoted as new bioactive secondary metabolites due to their structural analogy with mammal oxylipins. These compounds can be further postulated as possible markers for the monitoring of the physiological status of legume plants under different agronomical conditions. The results obtained can contribute to the successful development of future research in the field of plant physiology and nutrition, significantly contributing to the advance of the current knowledge on the biological role of phytoprostanes and phytofurans in plants and complex biological systems.

\section{Introduction}

In addition to the nutritional aspects of legume foods, which constitute valuable sources of proteins, slow-absorption carbohydrates, and mono and poly-unsaturated lipids, these crops are associated with diverse agronomical benefits, due to their capacity to fix atmospheric N. ${ }^{[1]}$ Hence, in light of these nutritional and agronomic advantages, the arable land dedicated to legume crops has increased to almost $300000 \mathrm{Ha}$ in the European Union in 2016, aimed at tackling the challenge of maintaining the production indicators, under the current circumstance of climate change and water shortage. ${ }^{[2]}$

Phytoprostanes (PhytoPs) are components of the oxidant-injury-sensing and signaling system of higher plants that contribute to plant defense, ${ }^{[3]}$ which result from the autoxidation of $\alpha$-linolenic acid (ALA, C18:3 n-3) ${ }^{[4]}$ in response to increased levels of reactive oxygen species (ROS) produced as a result of the plant's exposure to biotic and abiotic stress. Related to this, these compounds have been described in an array of edible and medicinal plants in diverse concentrations of up to $1900 \mathrm{ng}$ $\mathrm{mL}^{-1}$ in vegetable oils and up to $21659.80 \mathrm{ngg}^{-1}$ in solid plant foods. ${ }^{[5]}$
M. C. García-García, Dr. M. del Río Celestino

Center IFAPA La Mojonera, CAPDER, Junta de Andalucía

Camino San Nicolás 1, 04745 Almería, Spain

Dr. Á. Gil-Izquierdo, Prof. F. Ferreres, Dr. R. Domínguez-Perles

Group on Quality, Safety, and Bioactivity of Plant Foods

Department of Food Science and Technology

(CEBAS-CSIC)

University Campus Edif

25, 30100 Espinardo, Spain

E-mail: angelgil@cebas.cisc.es
Prof. C. Egea-Gilabert, Prof. J. A. Fernández

Technical University of Cartagena

Paseo Alfonso XIII 48, 30203 Cartagena, Spain

Prof. J. M. Galano, Prof. T. Durand, Dr. C. Oger Institut des Biomolécules Max Mousseron (IBMM)

UMR 5247

CNRS

University of Montpellier

ENSCM

34093 Montpellier, France 
This implies that they are part of the molecular mechanisms of plant cells for the correction of the redox imbalance. ${ }^{[6]}$ In this regard, these molecules are considered oxylipins (bioactive lipid metabolites derived from polyunsaturated fatty acids (PUFAs) via the cyclooxygenase, lipoxygenase, and cytochrome P450 pathways, ${ }^{[7]}$ but also produced due to non-enzymatic peroxidation of PUFAs ${ }^{[8]}$ ). The synthesis of these compounds in plant cells starts with the precursors $16-\mathrm{G}_{1^{-}}$and $9-\mathrm{G}_{1}$-phytoP, precursors of the diverse classes of cyclic compounds $\left(\mathrm{A}_{1}, \mathrm{~B}_{1}\right.$, $\mathrm{D}_{1}, \mathrm{E}_{1}, \mathrm{~F}_{1}, \mathrm{dJ}_{1}$, and $\left.\mathrm{L}_{1}-\mathrm{PhytoPs}\right) .{ }^{[9]}$ Moreover, recently, the occurrence of other plant oxylipins, the phytofurans (PhytoFs) has been described, being these preferentially synthesized under higher oxygen partial pressure $(>21 \%) .{ }^{[10,11]}$

To date, the value of PhytoPs and PhytoFs has been demonstrated as biomarkers of interest for the oxidative degradation of plant foods in the fields of plant nutrition and biotechnology. ${ }^{[3]}$ Also, these compounds have been suggested to be bioavailable and biologically active molecules in vivo in humans, after dietary intake, ${ }^{[5]}$ for instance, in respect to their capacity to modulate the response of the immune system ${ }^{[12-14]}$ and their anti-inflammatory activity. ${ }^{[15]}$ In this regard, the biological functions attributed to these plant oxylipins, in humans, have been demonstrated by recent studies on their bioavailability, immunomodulatory and anti-inflammatory activity, and structural analogy with human isoprostanes and prostaglandins..$^{[5,16-18]}$ However, their contribution to health in mammals has to be clearly ascertained within a complex network of signaling molecules and mediators, for which the accurate characterization of their concentration in the diverse food matrices is needed. ${ }^{[16]}$ According to this priority, sorting out the relevance of PhytoPs and PhytoFs within the population of secondary metabolites and signaling molecules of higher plants has not been completely addressed, ${ }^{[10,19]}$ with gaps of knowledge existing with regards to their physiological role in plants and the extent in which growth stress factors could modulate their concentration and thus, the final functionality foreseen in mammals.

To better understand the relevance of sustained deficit irrigation on the occurrence of PhytoPs and PhytoFs, as well as the importance of such isoprotanoids in legumes, pea (Pisum sativum L.), French bean (Phaseolus vulgaris L.), and mangetout (Pisum sativum L. ssp. arvense) were considered, as they are plant foods that are strongly established in modern diets. Hence, the isoprostanoid content was assessed in three species grown under normal control conditions with full irrigation and 50\% sustained deficit irrigation conditions. The results were further statistically processed to determine the usefulness of the total and individual content of PhytoPs/PhytoFs for the classification of the plant materials and evaluation of their agro-food and biological interest, in addition to applications as potential markers of agrophysiological status of legumes.

\section{Experimental Section}

\subsection{Chemical and Reagents}

The PhytoPs and PhytoFs standards were synthesized according to the procedures described in the literature ${ }^{[10,20-24]}$ and provided by the Institut des Biomolécules Max Mousseron (IBMM) (Montpellier, France). The synthetic isoprostane 8-iso-PGF $2 \mathrm{a}^{-}$ $\mathrm{d}_{4}$ was purchased from Cayman Chemicals (Ann Arbor, Michigan, USA). Hexane was obtained from Panreac (Castellar del Vallès, Barcelona, Spain), Bis-Tris (bis(2-hydroxyethyl) amino-tris (hydroxymethyl)methane) was purchased from Sigma-Aldrich (St. Louis, MO, USA), and all LC-MS grade solvents, methanol, and acetonitrile were from J.T. Baker (Phillipsburg, NJ, USA). The Strata solid-phase extraction

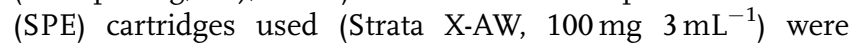
acquired from Phenomenex (Torrance, CA, USA).

\subsection{Plant Material, Experimental Conditions, and Irrigation Management}

The field trial was carried out in 2016/2017 at Instituto de Investigación y formación Agraria y Pesquera (IFAPA) Center "La Mojonera" - located in Almeria, in the SE of Spain $\left(36^{\circ} 48^{\prime} \mathrm{N}\right.$, $2^{\circ} 41^{\prime} \mathrm{W}$; altitude $142 \mathrm{~m}$ ) - in a greenhouse with two adjacent modules (East and West) with a total area of $800 \mathrm{~m}^{2}$ each. The plant material in the West greenhouse module consisted of Phaseolus vulgaris (French beans, cv. "Helda"), and three Pisum sativum varieties ("mangetout" (ssp. arvense) cv. "Tirabi," and two pea cvs. "BGE-033620" (retrieved from the Centro de Recursos Fitogenéticos-Instituto Nacional de Investigación y Tecnología Agraria y Alimentaria (Spain)) and the commercial cv. "Lincoln."

The experiments were conducted in a non-controlled environment, in traditional symmetric, multi-chapel greenhouses. The plants were grown organically and the biological control practices used were those previously reported by Specific Regulation of Integrated Production in green beans (2017). Weekly random monitoring of pests and disease symptoms was performed. All the plants were transplanted in October 2016, with a density of two plants per $\mathrm{m}^{2}$, including $10(n=10)$ true (field) replicates for each experimental condition. The minimum, average, and maximum relative humidity were 35.8 , 74.3, and $98.1 \%$, respectively. The minimum, average, and maximum air temperature were $12.2,17.2$, and $26.2^{\circ} \mathrm{C}$, respectively.

The soil received off-farm organic fertilizers selected in accordance with annex I of the European Union (EU) Regulation (Commission Regulation (EC) No 889/2008). Sheep manure was applied at a rate of $0.7 \mathrm{~kg} \mathrm{~m}^{-2}$. Its composition, expressed on a dry matter basis, was $45.6 \%$ organic matter, $17.7 \mathrm{~g} \mathrm{~kg}^{-1}$ total nitrogen, $889.0 \mathrm{mg} \mathrm{kg}^{-1}$ ammonium, $520.0 \mathrm{mg} \mathrm{kg}^{-1}$ nitrate, $2.2 \mathrm{~g} \mathrm{~kg}^{-1}$ phosphorus, $16.5 \mathrm{~g} \mathrm{~kg}^{-1}$ potassium, and $100.9 \mathrm{~g} \mathrm{~kg}^{-1}$ calcium.

A controlled drip irrigation system was used to supply water and nutrients. The nutrient solution was prepared starting with wellwater ( $\mathrm{pH}$ 7.3). The final concentrations in the nutrient solution were 6.0 meq $\mathrm{K}^{+} \mathrm{L}^{-1}, 2.2$ meq $\mathrm{Ca}^{2+} \mathrm{L}^{-1}$, a supplement of $10.0 \%$ humic acids (w/w), $16.0 \%$ fulvic acids (w/w), $\mathrm{K}_{2} \mathrm{SO}_{4}(52.0 \%$ $\mathrm{K}_{2} \mathrm{O}+45.0 \% \mathrm{SO}_{3}$ ), $24.0 \%$ free amino acids (w/w), 3.0\% organic nitrogen $(\mathrm{w} / \mathrm{w})$, and $0.3 \%$ ammoniacal nitrogen $(\mathrm{w} / \mathrm{w})$. This composition resulted in an electrical conductivity (EC) of $2.4 \mathrm{dS}$ $\mathrm{m}^{-1}$. The $\mathrm{pH}$ was adjusted to 6.5 when needed, using vinegar. The irrigation regimes were started seven days after transplanting. Two treatments (100.0 and 50.0\% water-holding capacity, Full-irrigation, FI and sustained deficit irrigation, SDI, respectively) of fertigation for each of the two greenhouse modules were arranged 
in a completely randomized design that included 35 legume plants per cultivar. The first and the final two plants at the upper and lower end of each row were not considered for harvesting, sampling, or measurements, resulting in 10 replicates $(n=10)$ per species and treatment. Two external rows were included in the experimental design as guards. The plants did not show any symptom of deficiency or toxicity.

During the period of maximum crop growth, considered as the highest production stage, a minimum duration of $30 \mathrm{~min}$ of fertigation (FI treatment) was required when the tensiometers indicated a surface tension of $22 \mathrm{cb}$ (set points based on substrate matric potential). The total volume of nutrient solution applied in each irrigation event was 60 and $30 \mathrm{~L} \mathrm{~m}^{-2}$ for the FI and SDI irrigation regimes, respectively. Harvesting was carried out between November 2016 and January 2017, when the fruits reached standard commercial sizes.

Legume-pod samples were taken from 10 randomly distributed plants in each experimental unit. The samples for analysis consisted in pods (French-bean and mangetout) and seeds (peas), as these were the most common edible format of each legume. Once harvested, the plant material was packaged in polypropylene plastic containers and stored at $-80^{\circ} \mathrm{C}$. These samples were lyophilized using freeze drying equipment (Telstar LyoQuest, Germany), and afterward ground in a mill (Janke \& Kunkel, mod. A10, IKA-Labortechnik) for about $20 \mathrm{~s}$ so that the powder could pass through a $0.5 \mathrm{~mm}$ screen, and stored at $-80^{\circ} \mathrm{C}$ until analysis.

\subsection{Extraction of Phytoprostanes and Phytofurans}

The PhytoPs and PhytoFs present in the legumes (P. vulgaris (French bean) and P. sativum ("mangetout" and pea)) were extracted by following the previously described methodology. ${ }^{[4]}$ The extracts were filtered through a SepPak classic $\mathrm{C}_{18}$ column (Waters Chromatography S.A., Barcelona, Spain), previously pre-conditioned with $10 \mathrm{~mL}$ of methanol and $10 \mathrm{~mL}$ of milli-Q water, and dried with $10 \mathrm{~mL}$ of air. One (1) $\mathrm{mL}$ of the filtered extract was dissolved in $10 \mathrm{~mL}$ of hexane, $2 \mathrm{~mL}$ of methanol, and $2 \mathrm{~mL}$ of BIS-TRIS buffer $(0.02 \mathrm{M}, \mathrm{HCl}, \mathrm{pH}=7)$ and the mixture was cleaned by SPE using previously activated Strata X-AW cartridges, according to the procedure described previously. ${ }^{[4,25]}$ The compounds eluted were dried using a SpeedVac concentrator (Savant SPD121P, Thermo Scientific, MA, USA), reconstituted with $200 \mu \mathrm{L}$ of milli-Q water/MeOH $(50: 50, \mathrm{v} / \mathrm{v})$, and filtered with a $0.45-\mu \mathrm{m}$ filter (Millipore, MA, USA).

\subsection{UHPL-ESI-QqQ-MS/MS Analysis of Phytoprostanes and Phytofurans}

Chromatographic separation of PhytoPs $(n=10)$ and PhytoFs $(n=3)$ was performed using an Ultra-High-Pressure Liquid Chromatograph (UHPLC-ESI-QqQ-MS/MS) coupled with an electrospray ionization (ESI) system and a 6460 triple quadrupole-MS/MS (Agilent Technologies, Waldbronn, Germany), according to the methodology previously developed and validated for PhytoPs and PhytoFs in our own group. ${ }^{[26,27]}$ The MS analysis was applied using multiple reaction monitoring operated in negative ESI mode (Figure 1).

\subsection{Statistical Analysis}

The design of the experiment was completely randomized with 10 replicates $(n=10)$, for each species and experimental condition. Results are presented as bar plots which show the means \pm SD. Data were analyzed using the Statistical Package for the Social Sciences (SPSS) 24.0 software package (LEAD Technologies, Inc., Chicago, USA). All data were subjected to a one-way analysis of variance (ANOVA). The fulfillment of the one-way ANOVA requirements, more specifically, the normal distribution of the residuals and the homogeneity of variance, was tested using the KolmogorovSmirnov (with Lilliefors correction) and Levene's tests, respectively. When statistical differences were identified, the variables were compared using Tukey's multiple range test. All statistical tests were performed at a $5.0 \%$ significance level.

The principal components analysis (PCA) was conducted as a pattern recognition unsupervised classification method. The number of dimensions kept for data analysis was evaluated by the respective eigenvalues (which should be greater than one) and by the total percentage of variance (that should be as great as possible) explained by the number of selected components. The number of plotted dimensions was chosen in order to allow meaningful interpretations, and to ensure their reliability.

\section{Results}

\subsection{Marketable Yield}

The comparison of the yield of the diverse species and varieties in response to irrigation deficit evidenced that only French bean (P. vulgaris) plants had a significantly lowered productivity under the SDI irrigation regime. In this regard, the commercial production of French beans ( $P$. vulgaris) under control conditions (FI), with a total production of $1.60 \mathrm{~kg} \mathrm{~m}^{-2}$, decreased by $32.5 \%$ for a total production of $1.08 \mathrm{~kg} \mathrm{~m}^{-2}$ when exposed to SDI. On the other hand, the yields of "mangetout" ( $P$. sativum ssp. arvense), "BGE-033620" pea, and "Lincoln" pea (both P. sativum), under both FI and SDI, were, on average, 0.57, 1.03, and $0.46 \mathrm{~kg} \mathrm{~m}^{-2}$, respectively, without significant differences found between irrigation regimes (Figure 2A).

The same trend was observed regarding weight per fruit/pod (Figure 1B). In this respect, the only significant difference between growing conditions corresponded to French beans (P. vulgaris) $(20$ and $15 \mathrm{~g}$ per edible fruit for plants grown applying FI and SDI, respectively). "Mangetout" ( $P$. sativum ssp. arvense) and the pea (P. sativum) varieties "BGE-033620" and "Lincoln" had values that were $74.7 \%$ lower relatively to $P$. vulgaris, on average, when grown under SDI (Figure 2B).

\subsection{Phytoprostane and Phytofuran Profiles}

The assessment of the PhytoPs and PhytoFs profiles of edible French beans ( $P$. vulgaris), pea ( $P$. sativum), and "mangetout" (P. sativum ssp. arvense) by UHPLC-ESI-QqQ-MS/MS allowed 


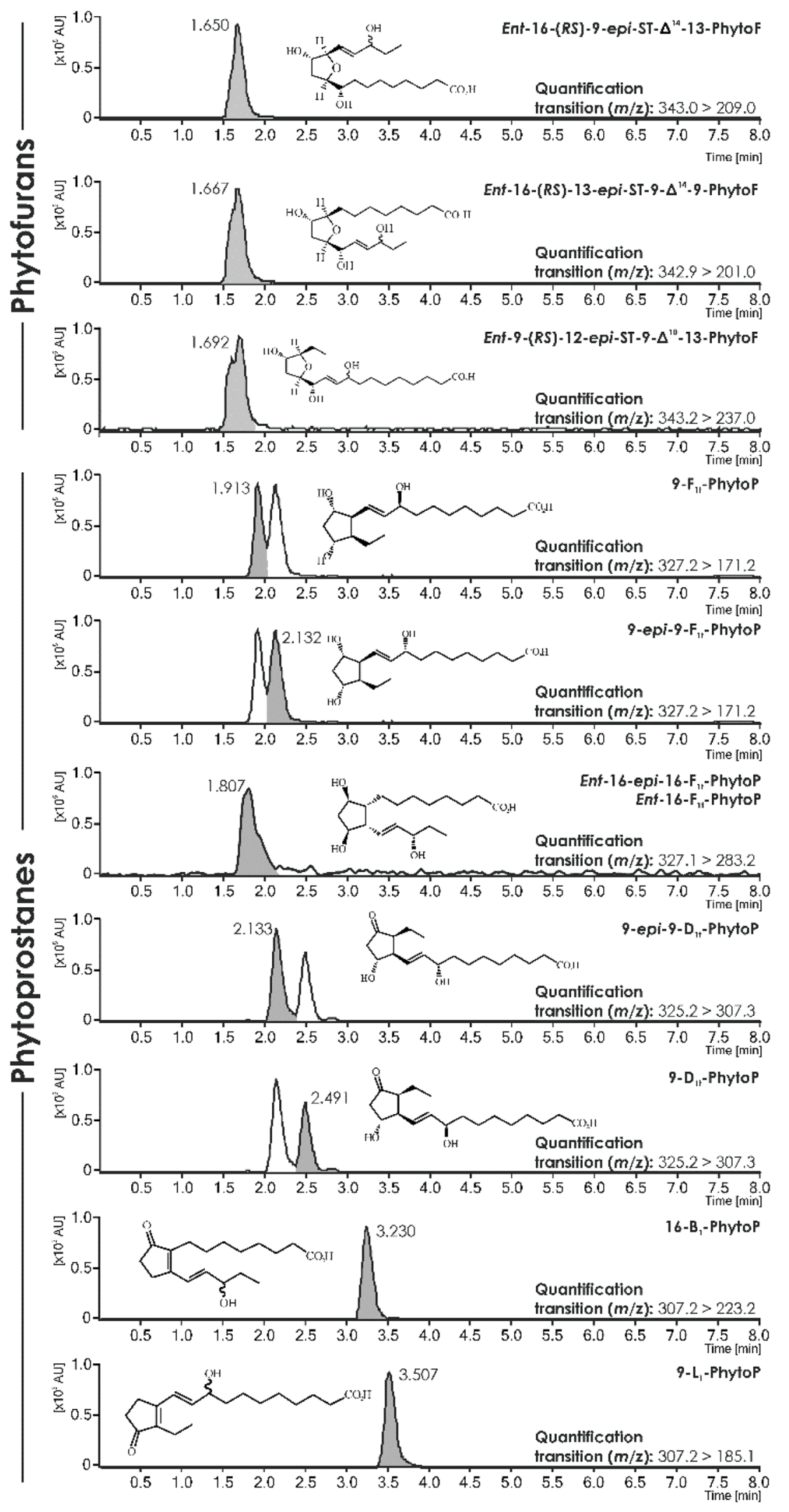

Figure 1. UHPLC-ESI-QqQ-MS/MS profile of the phytoprostanes and phytofurans found in pea (Pisum sativum L.), French beans (Phaseolus vulgaris L.), and mangetout (Pisum sativum L. ssp. arvense), with indication of their chemical structures and specific multiple reaction monitoring transition (MRM) considered for quantification. 

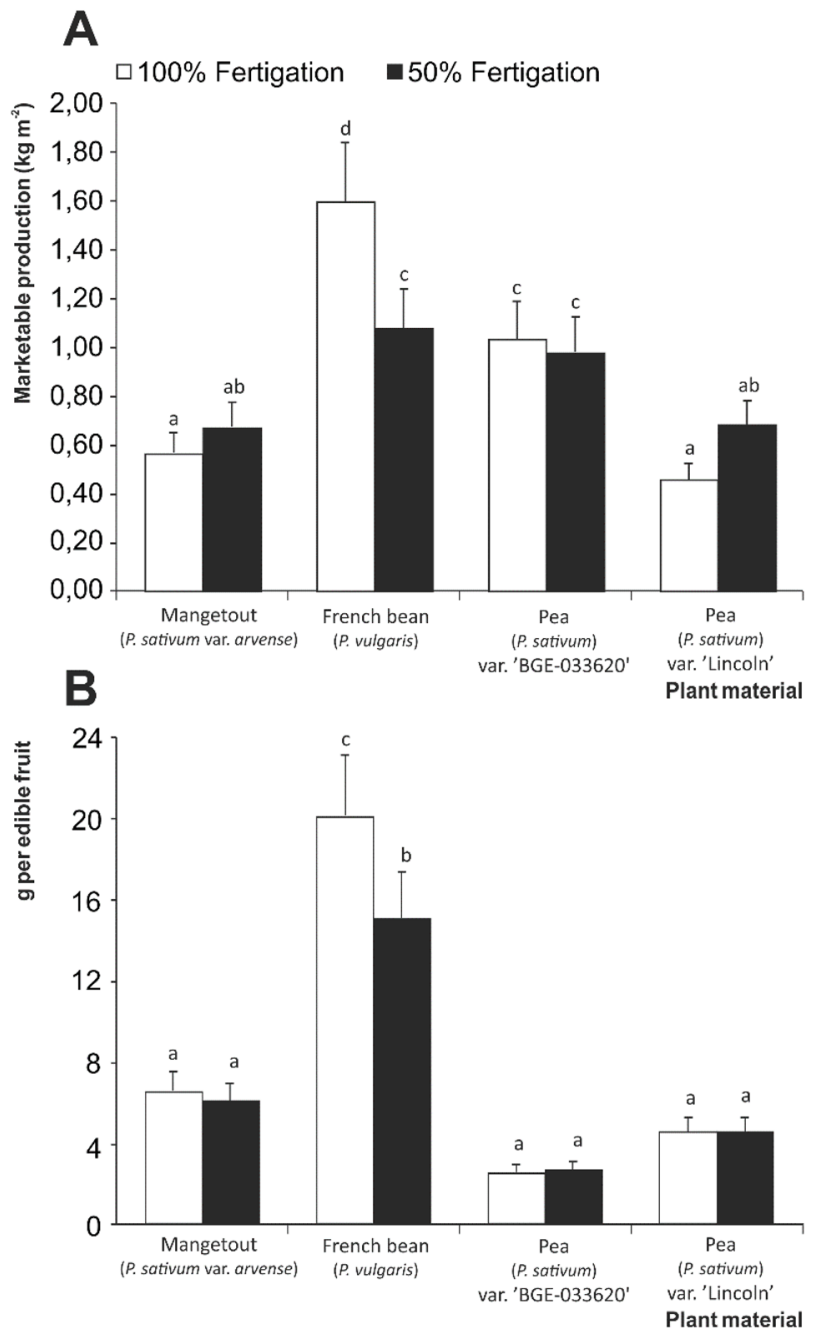

Figure 2. Marketable production (A) and average weight of the edible fruits (B) obtained from the separate crops under 50 and $100 \%$ irrigation. Bars with different lowercase letters are significantly different at $p<0.05$ according to Tukey's multiple range test.

for the detection of the presence of 9- $\mathrm{F}_{1 \mathrm{t}} \mathrm{PhytoP}$, 9-epi-9- $\mathrm{F}_{1 \mathrm{t}^{-}}$ PhytoP, ent-16- $\mathrm{F}_{1 \mathrm{t}}-\mathrm{Phyto}$, ent-16-epi-16- $\mathrm{F}_{1 \mathrm{t}}-\mathrm{Phyto}$, 9- $\mathrm{D}_{1 \mathrm{t}}-\mathrm{Phy}-$ toP, 9-epi-9- $\mathrm{D}_{1 \mathrm{t}}-\mathrm{PhytoP}, 16-\mathrm{B}_{1}$-PhytoP, 9- $\mathrm{L}_{1}-\mathrm{PhytoP}$, ent-16- $(R S)$ 9-epi-ST- $\Delta^{14}-10$-PhytoF, ent-9-(RS)-12-epi-ST- $\Delta^{10}-13$-PhytoF, and ent-16-(RS)-13-epi-ST- $\Delta^{14}$-9-PhytoF. The individual PhytoPs and PhytoFs were tentatively identified according to their order of elution in comparison with pure standards, as well as mass spectra and specific fragmentation patterns, considering the mass-to-charge ratio $(\mathrm{m} / \mathrm{z})$ (Figure 1$)$. Hence, the analysis of the PhytoPs profile revealed the absence of 9-epi-9- $\mathrm{D}_{1 \mathrm{t}}$-PhytoP and $9-\mathrm{D}_{1 \mathrm{t}}$-PhytoP in "mangetout" ( $P$. sativum ssp. arvense) and pea ( $P$. sativum cV. 'BGE-033620") grown under SDI as well as in French beans ( $P$ vulgaris) grown under the normal water regime (Figure 3). Moreover, ent-9-(RS)-12-epi-ST- $\Delta^{10}-13-\mathrm{PhytoF}$ and ent-16-(RS)-13-epi-ST- $\Delta^{14}$-9-PhytoF were not found in P. sativum ("Lincoln"), P. sativum ssp. arvense ("mangetout") and French beans $(P$. vulgaris) grown under both irrigation conditions (Figure 4).

\subsection{Concentration of Phytoprostanes and Phytofurans}

The highest concentration of total PhytoPs was found in $P$. sativum ssp. arvense $\left(26313.4 \mu \mathrm{g} 100 \mathrm{~g}^{-1} \mathrm{dw}\right)$, followed by both varieties of pea $\left(13275.5 \mu \mathrm{g} 100 \mathrm{~g}^{-1} \mathrm{dw}\right.$, on average), while French beans ( $P$. vulgaris) displayed the lowest concentration (2264.1 $\mu \mathrm{g} 100 \mathrm{~g}^{-1} \mathrm{dw}$ ) under FI (Figure 3).

Similarly, the concentration of individual PhytoPs in legume plants grown under FI regime decreased in the following order: "mangetout" ( $P$. sativum ssp. arvense) $>$ pea ( $P$. sativum; var. "BGE-033620" > var. "Lincoln") $>$ French bean (P. vulgaris). However, not all the individual PhytoPs contributed equally to the total amount (Figure 3). The most abundant PhytoPs were 9$\mathrm{F}_{1 \mathrm{t}^{-}}$PhytoP (Figure 3B) and ent-16-epi-16- $\mathrm{F}_{1 \mathrm{t}^{-}} \mathrm{Phyto} \mathrm{P}+$ ent-16- $\mathrm{F}_{1 \mathrm{t}^{-}}$ PhytoP (Figure 3C), which were found in the ranges 624.3$12034.5 \mu \mathrm{g} 100 \mathrm{~g}^{-1} \mathrm{dw}$ and $660.9-13454.3 \mu \mathrm{g} 100 \mathrm{~g}^{-1} \mathrm{dw}$, respectively. Significant differences between FI and SDI conditions were noticed for 9-epi-9- $\mathrm{F}_{1 \mathrm{t}}$-PhytoP (range 888.0$9872.0 \mu \mathrm{g} 100 \mathrm{~g}^{-1} \mathrm{dw}$ ) (Figure 3D) and 9-D $1 \mathrm{t}^{-}$PhytoP $(\leq 2055.0 \mu \mathrm{g}$ $100 \mathrm{~g}^{-1} \mathrm{dw}$ ) (Figure 3F). By contrast, under FI, the highest concentration of 9-epi-9- $\mathrm{D}_{1 \mathrm{t}}$-PhytoP (Figure 3E) was found in $P$. sativum var. "BGE-033620," with an average value of $1699.3 \mu \mathrm{g}$ $100 \mathrm{~g}^{-1} \mathrm{dw}$, while $P$. sativum var. arvense and $P$. sativum var. "Lincoln" exhibited 41.1 and $98.6 \%$ lower values relative to $P$. sativum var. "BGE-033620." The 16- $\mathrm{B}_{1}$ and 9- $\mathrm{L}_{1}$-PhytoPs (Figure $3 \mathrm{G}$ and $\mathrm{H}$, respectively) exhibited matching concentrations in both varieties of $P$. sativum and in $P$. satium ssp. arvense, with values ranging from 633.0 to 859.3 and from 386.9 to $597.9 \mu \mathrm{g} 100 \mathrm{~g}^{-1} \mathrm{dw}$, respectively. Interestingly, $P$. vulgaris was notable for having the lowest concentration of all the PhytoPs, with values ranging from 87.2 to $99.8 \%$ lower than the average found for P. sativum. In this regard, 9- $\mathrm{D}_{1 \mathrm{t}}-\mathrm{PhytoP}$ and 9-epi-9- $\mathrm{D}_{1 \mathrm{t}}$-PhytoP were almost absent in French beans under FI.

When analyzing the impact of SDI on the concentrations of total and individual PhytoPs in the legume plants, significant differences between the FI and SDI regimes were observed (Figure 3). Nonetheless, these differences were contrary in $P$. sativum relative to $P$. vulgaris. Thus, in $P$. sativum, the highest contents of both total and individual PhytoPs corresponded to plants grown with FI, with concentrations of total PhytoPs 1.5fold higher than those plants under the SDI regime. With respect to individual PhytoPs, the contents in "BGE-033620" and "Lincoln" pea ( $P$. sativum), and "mangetout" ( $P$. sativum ssp. arvense) control plants (FI) were up to 150-fold, 7-fold, and 58-fold higher, respectively, than in crops grown under SDI. This trend was especially relevant for ent-16- $\mathrm{F}_{1 \mathrm{t}}$-PhytoP, ent-16epi-16- $\mathrm{F}_{1 \mathrm{t}}-\mathrm{PhytoP}, 9-\mathrm{D}_{1 \mathrm{t}}-\mathrm{PhytoP}$, 9-epi-9- $\mathrm{D}_{1 \mathrm{t}}-\mathrm{PhytoP}, 16-\mathrm{B}_{1}-\mathrm{Phy}-$ toP, and $9-\mathrm{L}_{1}-\mathrm{Phyto}$, which were almost absent in $P$. sativum grown under water stress conditions. In $P$. vulgaris, plants grown with FI displayed total and individual PhytoPs concentrations that were $94.3 \%$ lower, on average, than those under SDI (Figure 3).

Similarly, when evaluating the content of PhytoFs, and specifically regarding total PhytoFs and ent-16-(RS)-9-epi-ST- $\Delta^{14}$. 10-PhytoFs, of P. sativum (peas and "mangetout") and P. vulgaris, an opposing trend was observed. In respect to total PhytoFs, $P$. sativum exhibited higher concentrations under control conditions (FI) that were up to fivefold higher than in plants 

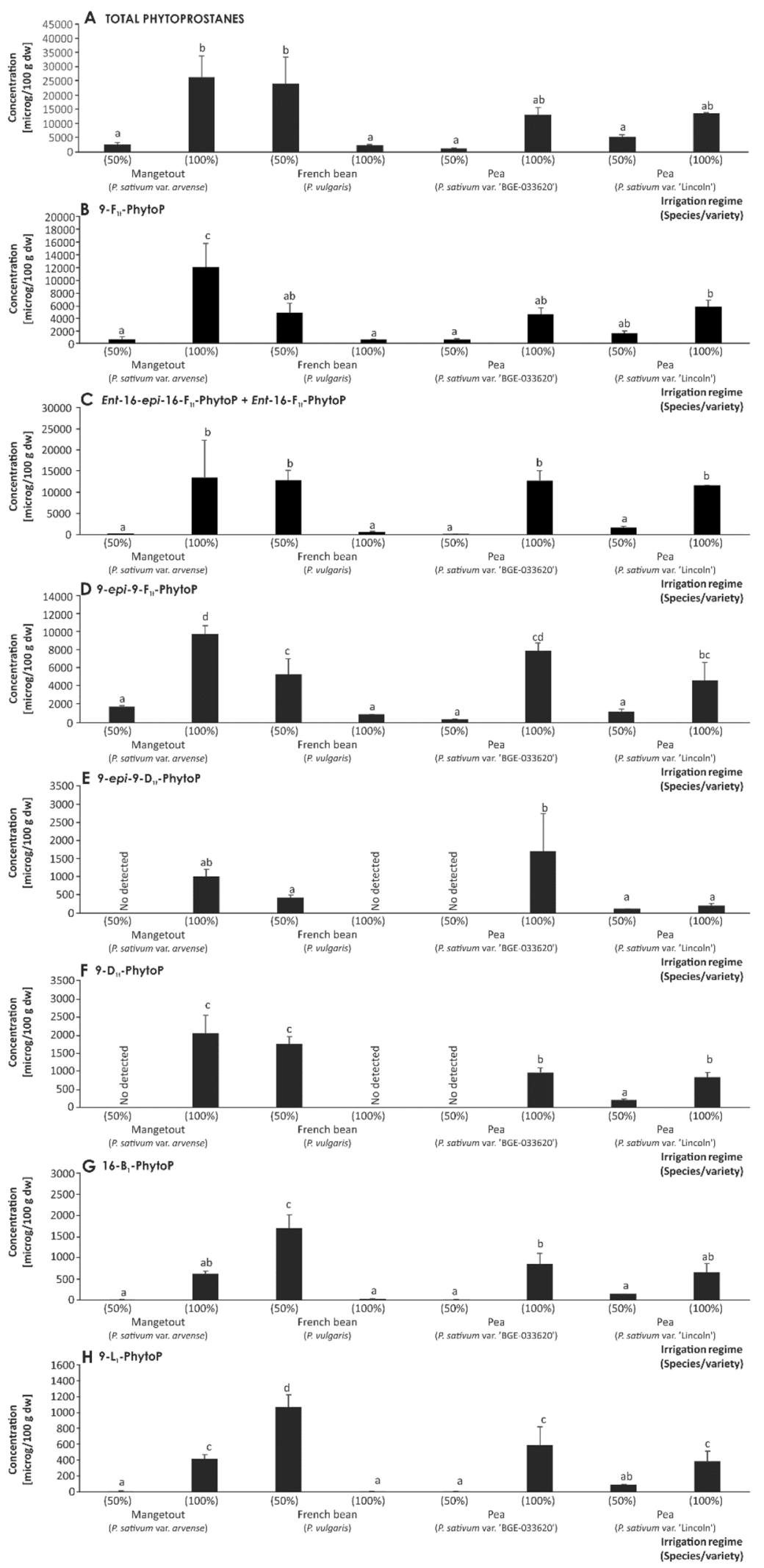

Figure 3. Total and individual phytoprostanes concentrations ( $\mu \mathrm{g} 100 \mathrm{~g}^{-1} \mathrm{dw}$ ) in edible parts of pea (Pisum sativum L.), French beans (Phaseolus vulgaris L.), and mangetout (Pisum sativum L. ssp. arvense) grown under normal (100.0\%) and sustained deficit (50.0\%) irrigation. Bars with different lowercase letters are significantly different at $p<0.05$ according to Tukey's multiple range test. 

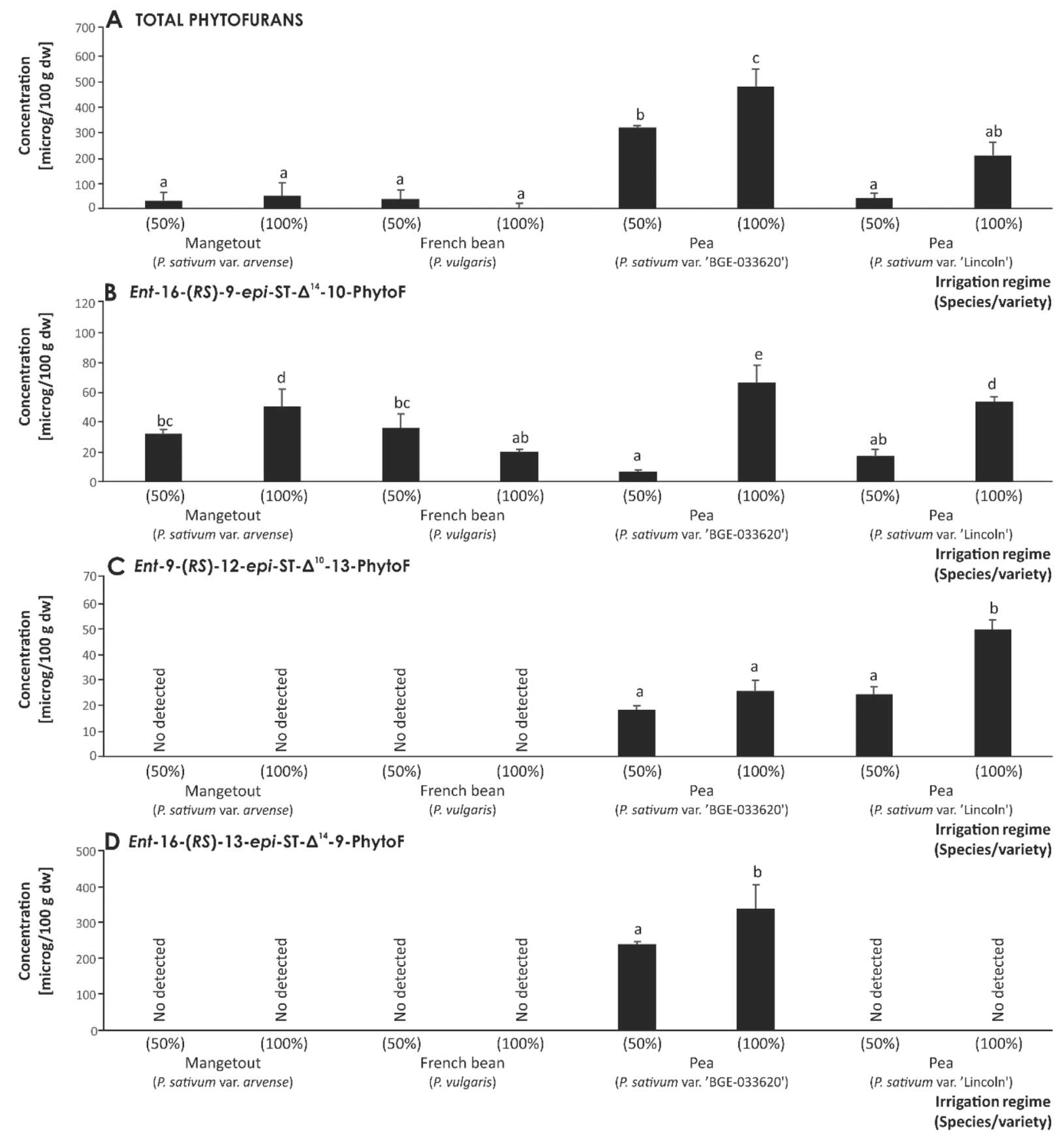

(P. sativum var. 'BGE-033620')

Irrigation regime (Species/variety)

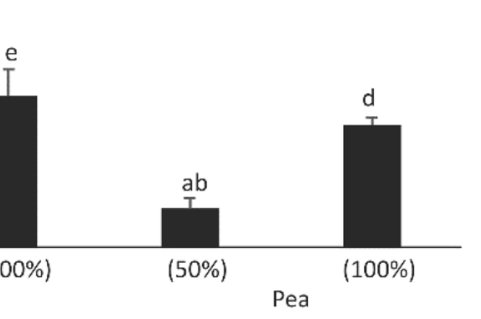

Irrigation regime (Species/variety)

Figure 4. Total and individual phytofurans concentrations ( $\mu \mathrm{g} 100 \mathrm{~g}^{-1} \mathrm{dw}$ ) in edible parts of pea (Pisum sativum L.), French beans (Phaseolus vulgaris L.), and mangetout (Pisum sativum L. ssp. arvense) grown under normal (100.0\%) and sustained deficit (50.0\%) irrigation. Bars with different lowercase letters are significantly different at $p<0.05$ according to Tukey's multiple range test.

grown under SDI (Figure 4A). On the other hand, regarding $P$. vulgaris, the highest concentration of total PhytoF was found in plants exposed to decreased irrigation (SDI) although the differences recorded were not statistically significant $(p>0.05)$ (Figure 4B).

As for the individual PhytoFs, ent-16-(RS)-9-epi-ST- $\Delta^{14}-10$ PhytoF was the only one present in all legume species and varieties assessed, remaining within the range of $19.6-66.0 \mu \mathrm{g}$
$100 \mathrm{~g}^{-1} \mathrm{dw}$ (Figure 4B). The highest concentration of ent-16$(R S)$-9-epi-ST- $\Delta^{14}-10$-PhytoF was found in the pea (P. sativum) variety "BGE-033620" (66.0 $\left.\mu \mathrm{g} 100 \mathrm{~g}^{-1} \mathrm{dw}\right)$, followed by the variety "Lincoln" and $P$. sativum ssp. arvense grown under $100.0 \%$ irrigation $\left(51.8 \mu \mathrm{g} 100 \mathrm{~g}^{-1} \mathrm{dw}\right.$, on average), with the lowest concentration corresponding to $P$. vulgaris $(19.6 \mu \mathrm{g}$ $\left.100 \mathrm{~g}^{-1} \mathrm{dw}\right)$. As described regarding PhytoPs, the highest concentrations of ent-16-(RS)-9-epi-ST- $\Delta^{14}-10$-PhytoF were found 
in $P$. sativum var. arvense and $P$. sativum ("BGE-033620" and "Lincoln") under 100.0\% irrigation (50.1, 66.0, and $53.6 \mu \mathrm{g}$ $100 \mathrm{~g}^{-1} \mathrm{dw}$, respectively). These concentrations surpassed the level in plants grown at $50.0 \%$ irrigation regime by $35.9,90.4$, and $68.3 \%$, respectively. Interestingly, the opposite trend was found for French bean; the concentration in plants exposed to SDI $\left(35.8 \mu \mathrm{g} 100 \mathrm{~g}^{-1} \mathrm{dw}\right)$ was higher than in plants grown under FI control conditions $\left(19.6 \mu \mathrm{g} 100 \mathrm{~g}^{-1} \mathrm{dw}\right)$ (Figure 4B). On the other hand, ent-9-(RS)-12-epi-ST- $\Delta^{10}-13-\mathrm{PhytoF}$ and ent-16-(RS)13-epi-ST- $\Delta^{14}$-9-PhytoF (Figure $4 \mathrm{C}$ and D, respectively) were under the limit of detection of the analytical technique for $P$. sativum var. arvense and $P$. vulgaris. The highest level of ent-9(RS)-12-epi-ST- $\Delta^{10}-13$-PhytoF was found in $P$. sativum var. "Lincoln" grown under FI conditions $\left(49.9 \mu \mathrm{g} 100 \mathrm{~g}^{-1} \mathrm{dw}\right)$, surpassing the concentration observed in plants of the same variety grown under SDI and in the variety "BGE-033620" grown under both FI and SDI regimes $\left(22.8 \mu \mathrm{g} 100 \mathrm{~g}^{-1} \mathrm{dw}\right.$, on average). Lastly, ent-16-(RS)-13-epi-ST- $\Delta^{14}-9$-PhytoF was only detected in $P$. sativum var. "BGE-033620," again corresponding to the highest concentration in plants grown under FI conditions $\left(337.0 \mu \mathrm{g} 100 \mathrm{~g}^{-1} \mathrm{dw}\right)$ than in SDI $\left(239.0 \mu \mathrm{g} 100 \mathrm{~g}^{-1} \mathrm{dw}\right)$.

When correlating the PhytoPs and PhytoFs profile and phylogenetic classification, a heatmap was obtained that represented the level of isoprostanoids identified across the four legume varieties considered in our study. Interestingly, a phylogenetic cluster was found which grouped all $P$. sativum varieties that contained a similar composition of PhytoPs and PhytoFs (Figure 5).

\subsection{Principal Component Analysis}

The results from the loadings of the variables included in the PCA design (total and individual PhytoPs and PhytoFs), showed that mainly, the total PhytoPs (0.857), 9- $\mathrm{F}_{1 \mathrm{t}}$-PhytoP (0.720), 9epi-9- $\mathrm{F}_{1 \mathrm{t}}$-PhytoP (0.926), ent-16- $\mathrm{F}_{1 \mathrm{t}}$-PhytoP + ent-16-epi-16- $\mathrm{F}_{1 \mathrm{t}}{ }^{-}$ PhytoP (0.887), 9- $\mathrm{D}_{1 \mathrm{t}}$-PhytoP (0.853), and 9- $\mathrm{L}_{1}$-PhytoP (0.693) were the dominant factors contributing to the first principal component (PC1), which explained $56.7 \%$ of the total variability (Figure 6). Total PhytoFs and ent-16-(RS)-13-epi-ST- $\Delta^{14}-9$ PhytoF were the most relevant variables contributing to PC2, which represented $19.6 \%$ of the total variability. Hence, the combination of PC1 (56.7\%) and PC2 (19.6\%) explained 76.3\% of the total variability, high enough to represent most of the variables.

Based on the cluster analysis conducted (Figure 5), the samples corresponding to the diverse legumes species and varieties were clearly classified into three groups with Euclidean distances greater than 1 ; these can be further understood along with the PCA, according to their clusters in the PC1 vs PC2 plot. On the one hand, the samples obtained from "mangetout" (P. sativum var. arvense) and pea ( $P$. sativum) plants exposed to sustained deficit irrigation and French bean ( $P$. vulgaris) plants grown under control conditions comprised the first group. The plant material from "mangetout" and pea grown under FI and from French bean exposed to SDI, in turn, was split into two groups comprised by the $P$. sativum ("mangetout" (ssp. arvense), "Lincoln," and "033620-BGE") and by French bean

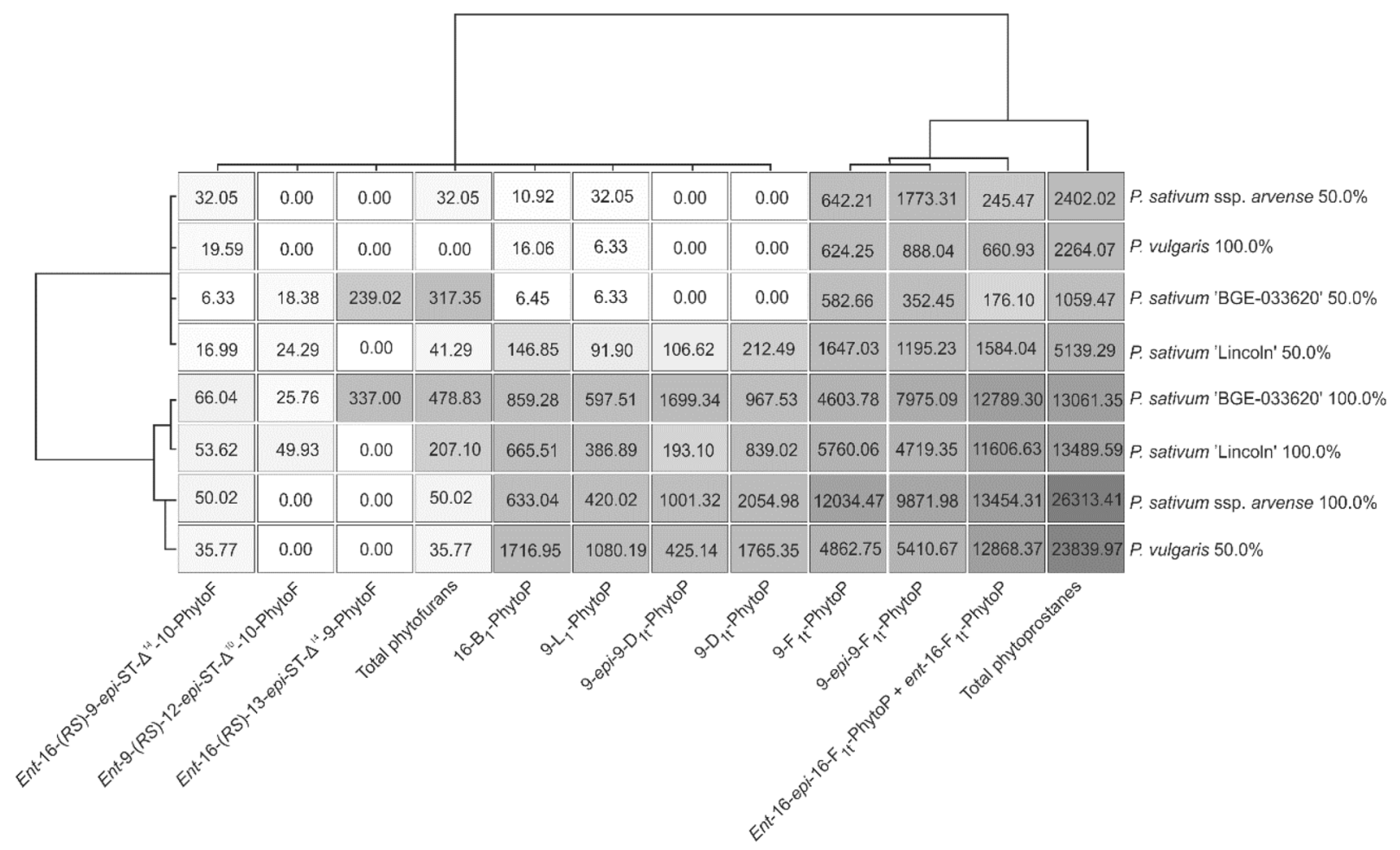

Figure 5. Hierarchical cluster analysis of isoprostanoid derivatives of pea (Pisum sativum L.), French beans (Phaseolus vulgaris $L$.), and mangetout (Pisum sativum L. ssp. arvense) grown under normal (100.0\%) and sustained deficit $(50.0 \%)$ irrigation. Results are expressed as means $\left(\mu \mathrm{g} 100 \mathrm{~g}^{-1} \mathrm{dw}\right)$ from ten field replicates per species/variety and growing condition. 


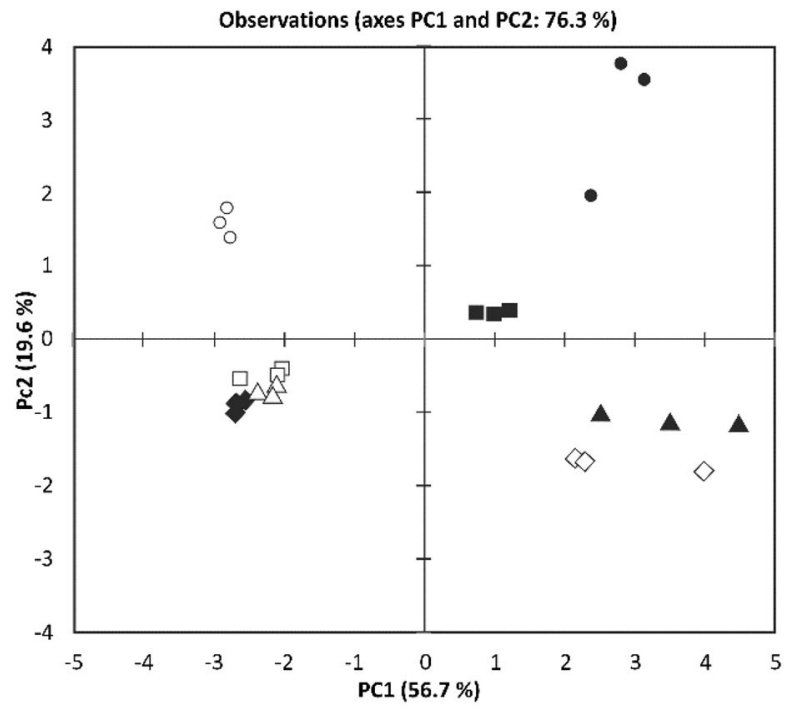

- Pisum sativum var. 'BGE-033620' $(50.0 \%)$

$\square$ Pisum sativum var. 'Lincoln' $(50.0 \%)$

$\triangle$ Pisum sativum spp. arvense (50.0\%)

$\diamond$ Phaseolus vulgaris $(50.0 \%)$

- Pisum sativum var. 'BGE-033620' $(100.0 \%)$

- Pisum sativum var. 'Lincoln' (100.0\%)

A Pisum sativum spp. arvense (100.0\%)

- Phaseolus vulgaris (100.0\%)

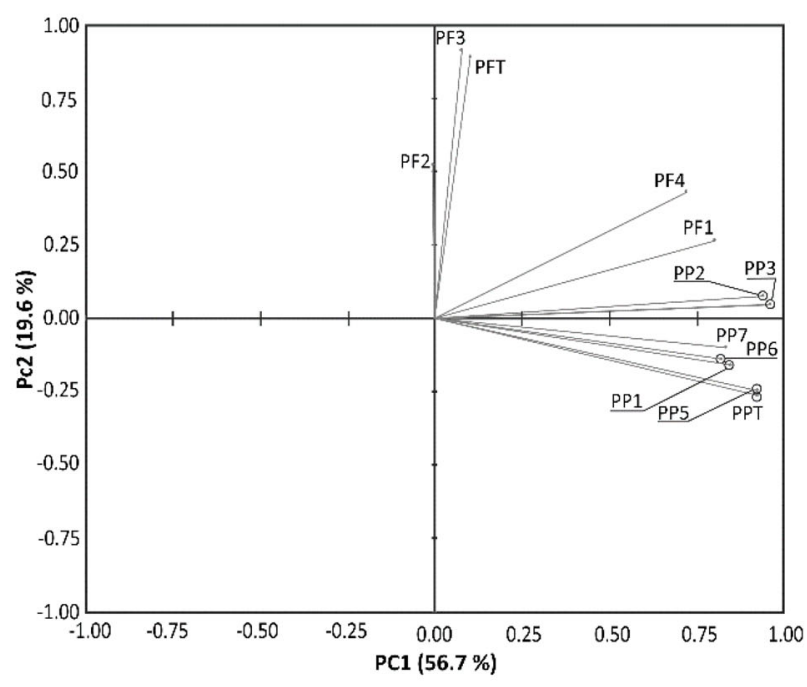

TPP, Total phytoprostanes

PP1, 9-F t-PhytoP

PP2, Ent-16-epi-16-F t-PhytoP + Ent-16-F t-PhytoP

PP3, 9-epi-9-F,t-PhytoP

PP4, 9-epi-9-D 1 t-PhytoP

PP5, 9-D t-PhytoP

PP6, 16- $B_{1}-$ Phyto + Ent-16- $B_{1}-$ PhytoP

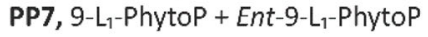

TPFs, Total phytofurans

PF1, Ent-16-(RS)-9-epi-ST- $\Delta^{14}-10-P h y t o F$

PF2, Ent-9-(RS)-12-epi-ST- $\Delta^{10}-13-$ PhytoF

PF3, Ent-16-(RS)-13-epi-ST- $\Delta^{14}-9-\mathrm{PhytoF}$

Figure 6. Principal components analysis of individual and total phytoprostanes and phytofurans in pea (Pisum sativum L.), French beans (Phaseolus vulgaris L.), and mangetout (Pisum sativum L. ssp. arvense) grown under normal (100.0\%) and sustained deficit (50.0\%) irrigation.

(Figure 5 and 6). This classification was further demonstrated by the distribution of samples in the PCA biplot, in which $P$. sativum plants grown under control (FI) conditions and $P$. vulgaris plants grown under SDI were placed on the right, with positive PC1 values. Again, within this subgroup, the peas were clearly differentiated, appearing in the upper right quadrant, with PhytoFs being the most relevant factor that influenced the classification of the separate legume species and varieties, whilst total and individual PhytoPs (the major contributors to PC1) were responsible for the discrimination of plants grown under FI or SDI. Samples from $P$. sativum and $P$. vulgaris plants grown under SDI and FI regimes, respectively, were placed on the left side of the PCA biplot. Only the P. sativum var. "BGE-033620" was clearly separated from the other three legumes analyzed by PC2; and this was mainly influenced by the concentrations of total PhytoFs and ent-16-(RS)-13-epi-ST- $\Delta^{14}-9-$ PhytoF.

\section{Discussion}

The characterization of the value of an array of legume species and varieties as a source of dietary PhytoPs and PhytoFs begun with the assessments of the evaluated crops' basic indicators of productivity in order to establish the framework of the study. In this respect, the pod yield of French bean ( $P$. vulgaris) was lower than the reported by the Andalusian Agricultural Council (García-García et al., 2016), with mean values of around $1.9 \mathrm{~kg} \mathrm{~m}^{-2}$. ${ }^{[2]}$ This lower yield could be attributable to the fact that the trial was carried out during a period which featured climatic conditions that were less favorable for its cultivation. On the other hand, the fresh pea pod yields in our study were similar to those previously reported in the scientific literature. ${ }^{[28,30]}$ These previous works revealed that the yield of fresh pods of pea (P. sativum) crops ranged from 0.92 to $1.33 \mathrm{~kg} \mathrm{~m}^{-2}$ under specific ecological conditions, ${ }^{[30]}$ demonstrating that the sowing time had a highly significant effect on this indicator. Thus, the fresh pod yield when sowing in autumn $\left(1.33 \mathrm{~kg} \mathrm{~m}^{-2}\right)$ was higher than when sowing in spring $\left(0.92 \mathrm{~kg} \mathrm{~m}^{-2}\right)$. In this sense, the results further demonstrated that the lack of moisture and high air temperature in spring negatively influenced the yield of pea crops. Also, the yield was significantly affected by additional limiting factors, such as an excessive deficit or surplus of water and extreme temperatures. ${ }^{[28]}$

In connection with the aforementioned impact of the climatic conditions, the analysis of the results retrieved demonstrated that the effect of sustained deficit irrigation was dependent on its frequency, length, and intensity, and on the growth stage at the start of the stress condition. In this regard, the information 
available in the literature supports the sensitivity of $P$. vulgaris to water shortage, especially during flowering initiation and development. Water stress during these stages results in excessive flowering, premature pods, and the abortion of seeds ${ }^{[31,32]}$ which directly affect the final yield. ${ }^{[33]}$ Also, sustained deficit irrigation has been related to a reduction of the aboveground biomass and a lower number of pods and seeds per pod. However, in addition to the production parameters, sustained deficit irrigation also affects mineral nutrition in legume plants, by reducing the uptake of phosphorus, as well as the concentration, distribution, and fixing of atmospheric nitrogen. ${ }^{[32,34]}$

Our results are in agreement with those of Martelo-Núñez et al., ${ }^{[35]}$ who demonstrated that the irrigation regime was especially relevant for the production of French beans $(P$. vulgaris), which were more sensitive than other legume crops to water stress. This is supported by the fact that in the present study, $P$. vulgaris was the only crop that was shown to have significant differences depending on the irrigation conditions (also in terms of PhytoPs and PhytoFs concentration, which could be considered, according to the results, as reliable markers of oxidative stress in plant physiology).

Apart from the impact of irrigation deficit on yield parameters, and as a core objective of the present study, this work reports, for the first time, on the PhytoP and PhytoF profiles not only of legumes, but also of edible annual plants. In this regard, to date, the information available on the concentration of PhytoPs in plant foods, regarding the range of plant foods assessed for these oxylipins, has revealed the occurrence of compounds from the classes $\mathrm{A}_{1^{-}}, \mathrm{B}_{1^{-}}, \mathrm{E}_{1^{-}}$, and $\mathrm{F}_{1}$, with each class representing a complex isomeric mixture that consists of two series ( 9 and 16), each integrated by 16 stereoisomers. ${ }^{[36]}$ In addition, the influence of the plant matrix and manufacturing processes on the contents of such compounds has been described. Thus, while in extra virgin olive oil, Collado-González et al. identified the presence of ent-16-epi-16- $\mathrm{F}_{1 \mathrm{t}}$-PhytoP, ent-16$\mathrm{F}_{1 \mathrm{t}}$-PhytoP, 9-epi-9- $\mathrm{D}_{1 \mathrm{t}}$-PhytoP, 9- $\mathrm{D}_{1 \mathrm{t}}$-PhytoP, and 16- $\mathrm{B}_{1}$-PhytoP, in olive drupes, $16-B_{1}$-PhytoP was the only coincident compound, ${ }^{[4]}$ revealing the chemical transformation occurring during the extraction and processing practices. Such differences were also found for the range of legumes species evaluated in the present work, which showed the high discrepancy in the occurrence of almost all the PhytoPs in peas that contrasted with the near absence of $9-\mathrm{F}_{1 \mathrm{t}}$-PhytoP and 9-epi-9- $\mathrm{F}_{1 \mathrm{t}}$-PhytoP in $P$. sativum grown under sustained deficit irrigation, as well as in $P$. vulgaris grown under control $(100.0 \%)$ water supply.

Diverse factors could have been responsible for these results, namely the distinct genetic information carried by the separate legume species/varieties that might entail distinct concentrations of ALA, ${ }^{[36]}$ as well as additional PUFAs. ${ }^{[4,18]}$ However, in respect to the relevance of the PUFAs' profile for the final content of PhytoPs and PhytoFs, a weak or even a lack of significant correlation between the ALA concentration and the level of these plant oxylipins has been recently reported, ${ }^{[4,26,37]}$ which could be due to the involvement of ALA in additional reactions aside from the peroxidation for PhytoPs and PhytoFs (such as enzymatic pathways to jasmonic acid synthesis). ${ }^{[38]}$ On the other hand, the different sensitivity of these species/ varieties with regards to the generation of ROS in cells and tissues as a consequence of growing under an abiotic stress, should be also considered. Indeed, this factor is much relevant because of the implication of ROS in the promotion of oxidative reactions that are responsible for the synthesis of PhytoPs and PhytoFs. ${ }^{[4,10]}$

The wide range of PhytoPs and PhytoFs identified to date in vegetables, together with their structural similarity with bioactive human isoprostanes and prostaglandins, have boosted the current search for the bioactivity of these oxylipins within the frame of a variety of powerful biological mechanisms of action and pathophysiological situations. ${ }^{[4]}$ Indeed, the structural coincidences between plant and mammals oxylipins suggest the ability of PhytoPs and PhytoFs to have similar mechanisms of action that could modify a range of molecular pathways mimicking the activity that has already been described for the mammalian compounds. ${ }^{[5]}$ However, to date, only PhytoPs have been (partially) characterized on their ability to modulate the activity of antigen-presenting cells and the immune response, by polarizing this toward Th2 (pro-allergenic) or as anti-inflammatory compounds capable of modulating the translocation of NF- $\kappa \mathrm{B} .{ }^{[14,33,39]}$

In the light of the promising biological activity of these compounds, the most suitable plant matrix according to its value as a dietary source of these PhytoPs and PhytoFs, should be found. Hence, the analysis of the PhytoPs found in P. sativum and $P$. vulgaris revealed concentrations at the millimolar level, which was much higher than those described previously in other higher plant species (always at the nanomolar range). ${ }^{[5]}$ It is also necessary to take into consideration the previous evaluations of perennial crops (olives ${ }^{[4]}$ and almonds ${ }^{[20]}$ ) that have a more efficient mechanism for the homeostasis of the redox system when grown under adverse, abiotic-stress conditions. In this respect, it is important to note that the manufacturing practices of diverse industries and food-products result in critical differences in the final content of PhytoPs, ${ }^{[4,18]}$ which informs on the propensity of such compounds to be synthesized when the proper conditions are met. However, despite the different concentrations of PhytoPs and PhytoFs already reported in the wide range of plant foods characterized thus far, the data available on their relative abundance point to subclass $F_{1}$ being the predominant one, in agreement with the results retrieved from the characterization of the PhytoPs and PhytoFs content of $P$. sativum and $P$. vulgaris. These results suggest that this subclass is the most interesting candidate, and should be evaluated on their biological and functional properties in humans. Also, their use as reliable markers of the oxidative degradation of plant lipids should be further investigated. ${ }^{[36,40]}$

When analyzing the impact of sustained deficit irrigation on the concentrations of total and individual PhytoPs in legume plants, significant differences between the FI and SDI regimes were observed (Figure 3). Nonetheless, the different trends of the changes observed in the response of both $P$. sativum relative to $P$. vulgaris could be attributed to the distinct sensitivity to abiotic stress (irrigation deficit), which was higher in P. vulgaris than in $P$. sativum. In this sense, to date, it has been reported that legumes, such as those belonging to the species $P$. sativum, characterized by the export of amides (principally asparagine and glutamine) into the nodule xylem, are generally more tolerant to drought than others such as Phaseolus spp. ${ }^{[41]}$ At present, this 
differential sensitivity entails the production of higher levels of ROS in the former, whilst in the latter even greater irrigation deficits would be required to significantly modify the concentrations of PhytoPs and PhytoFs. Indeed, PhytoPs have also been demonstrated (together with jasmonic acid) to be able to activate the expression of stress response genes, resulting in enhanced protection from subsequent oxidative stress events. ${ }^{[3,6]}$

The close relationship between the legume species and the level of PhytoPs and PhytoFs was further confirmed by the heatmap and PCA analysis conducted, which showed a phylogenetic clustering between those species varieties, as defined by similar ranges of these plants oxylipins.

\section{Conclusions}

As previously stated, PhytoPs and PhytoFs have been promoted as bioactive oxylipins that are present in plant foods, according to their structural analogy with human isoprostanoids. In this respect, the characterization of new dietary sources of these compounds remains a relevant issue for guaranteeing the further characterizations of their bioavailability and biological functions. To the best of our knowledge, this is the first description of the value of legume foods as a dietary source of PhytoPs and PhytoFs with the highest concentration found to date in solid plant foods, which provides meaningful information on the concentration of these plant oxylipins in edible plant material, evidencing the close link between the physiological features of the species considered and the changes in PhytoPs and PhytoFs accumulation in response to stress. Hence, the data obtained provide evidences on the concentration of these compounds in legumes, which is highly relevant due to the increasing presence of legumes in diets, in light of the current trend of replacing animal sources of essential nutrients with plant ones. Related with this, the raising proportion of these foods in diets ensures a regular and abundant intake of these compounds. Interestingly, the present work shows $P$. sativum ssp. arvense ("mangetout") as the most valuable source of PhytoPs, while for PhytoFs, P. peas seems to be the best option, even within the frame of abiotic stress, a scenario that is becoming more common given the current changing climate. Thus, the most important contribution to the total amount of PhytoPs and PhytoFs was provided by $9-\mathrm{F}_{1 \mathrm{t}}$-PhytoP and ent-16(RS)-13-epi-ST- $\Delta^{14}$-9-PhytoF, respectively. The information obtained has identified a valuable food matrix that is suitable for inclusion in nutrition trials devoted to the evaluation of the in vivo bioavailability and biological activity of such compounds, when legumes are included as a dietary source. These assays will provide not only critical information on the biological power of cyclopentanone compounds, but also information on the synergic and/or antagonistic activity involving other bioactive compounds present in plant foods.

\section{Abbreviations}

ALA, a linolenic acid; ANOVA, analysis of variance; EC, electoral conductivity; EU, European Union; PCA, principal component analysis; PhytoFs, phytofurans; PhytoPs, phytoprostanes; SD, standard deviation; $\mathrm{SPE}$, solid phase extraction; ROS, reactive oxygen species; UHPLC-ESI-
QqQ-MS/MS, ultra-high performance liquid chromatography coupled to electrospray ionization and mass spectrometer with triple quadrupole technology.

\section{Acknowledgments}

The authors wish to express their thanks to the projects PP.AVA. AVA201601.7 and PP.TRA.TRA201600.9 and to FEDER for the funding of this research. This research was also funded by the European Union's Seventh Framework Programme for Research, Technological Development and Demonstration under grant agreement no. 613781, project EUROLEGUME, the "Fundación Séneca de la Región de Murcia" Grupo de Excelencia 19900/GERM/15, and the Spanish project AGL2017-83386-R from the Spanish Ministry of Science, Innovation and Universities. This work is included in the framework of the collaboration between the Spanish Research Council (CEBAS-CSIC) and CNRS-University of Montpellier by "Projets Internationaux de Cooperation Scientifique" (PICS-2015-261141). R.D.P. was supported by a postdoctoral contract (Juan de la Cierva de Incorporación ICJI-2015-25373) from the Ministry of Economy, Industry and Competitiveness of Spain. The authors thank the English expert reviewer (Dr. Mario Fon) for the revision of the English style and grammar.

\section{Conflict of Interest}

The authors declare no conflict of interest.

\section{Keywords}

abiotic stress, legumes, Phaseolus vulgaris, Pisum sativum, plant oxylipins

[1] L. Lepse, S. Dane, S. Zeipina, R. Dominguez-Perles, E. A. Rosa, J. Sci. Food Agric. 2017, 97, 4334.

[2] UNESCO: World Water Assessment Programme, People and the Planet 2003.

[3] J. R. Araujo, E. Keating, F. Martel, Curr. Diab. Rep. 2015, 15, 569.

[4] M. Barbosa, J. Collado-Gonzalez, P. B. Andrade, F. Ferreres, P. Valentao, J. M. Galano, T. Durand, A. Gil-Izquierdo, J. Agric. Food Chem. 2015, 63, 6466.

[5] S. Medina, A. Gil-Izquierdo, T. Durand, F. Ferreres, R. DominguezPerles, Antioxidants 2018, 7, 165.

[6] A. Gonzalez-Bulnes, S. Astiz, C. Ovilo, C. Garcia-Contreras, M. Vazquez-Gomez, Curr. Pharm. Biotechnol. 2016, 17, 573.

[7] P. Chavan-Gautam, A. Rani, D. J. Freeman, Adv. Clin. Chem. 2018, 84, 209.

[8] M. Martinez-Ballesta, A. Gil-Izquierdo, C. Garcia-Viguera, R. Dominguez-Perles, Foods 2018, 7, 72.

[9] U. Jahn, J. M. Galano, T. Durand, Prostaglandins Leukot. Essent. Fatty Acids 2010, 82, 83.

[10] C. Cuyamendous, K. S. Leung, T. Durand, J. C. Lee, C. Oger, J. M. Galano, Chem. Commun. 2015, 51, 15696.

[11] J. P. Fessel, N. A. Porter, K. P. Moore, J. R. Sheller, L. J. Roberts, Proc. Natl. Acad. Sci. 2002, 99, 16713.

[12] S. Gilles, V. Mariani, M. Bryce, M. J. Mueller, J. Ring, T. Jakob, S. Pastore, H. Behrendt, C. Traidl-Hoffmann, J. Immunol. 2009, 182, 6653.

[13] V. Mariani, S. Gilles, T. Jakob, M. Thiel, M. J. Mueller, J. Ring, H. Behrendt, C. Traidl-Hoffmann, J. Immunol. 2007, 178, 7623. 
[14] C. Traidl-Hoffmann, V. Mariani, H. Hochrein, K. Karg, H. Wagner, J. Ring, M. J. Mueller, T. Jakob, H. Behrendt, J. Exp. Med. 2005, 201, 627.

[15] D. S. Straus, C. K. Glass, Med. Res. Rev. 2001, 21, 185.

[16] A. Barden, E. Mas, P. Henry, T. Durand, J. M. Galano, L. J. Roberts, K. D. Croft, T. A. Mori, Free Radic. Res. 2011, 45, 469.

[17] A. Dupuy, P. Le Faouder, C. Vigor, C. Oger, J. M. Galano, C. Dray, J. C. Lee, P. Valet, C. Gladine, T. Durand, J. Bertrand-Michel, Anal. Chim. Acta 2016, 921, 46.

[18] K. Karg, K. Karg, V. M. Dirsch, K. Karg, V. M. Dirsch, A. M. Vollmar, J.L. Cracowski, F. Laporte, M. J. Mueller, Free Radic. Res. 2007, 41, 25.

[19] M. E. Yonny, A. Rodríguez Torresi, C. Cuyamendous, G. Réversat, C. Oger, J.-M. Galano, T. Durand, C. Vigor, M. A. Nazareno, J. Agric. Food Chem. 2016, 64, 8296.

[20] A. Carrasco-Del Amor, J. Collado-Gonzalez, E. Aguayo, A. Guy, J. Galano, T. Durand, A. Gil-Izquierdo, Rsc Adv. 2015, 5, 51233.

[21] C. Cuyamendous, K. S. Leung, V. Bultel-Poncé, A. Guy, T. Durand, J. M. Galano, J. C. Y. Lee, C. Oger, Eur.J. Org. Chem. 2017, 2017, 2486.

[22] S. El Fangour, A. Guy, V. Despres, J. P. Vidal, J. C. Rossi, T. Durand, J. Org. Chem. 2004, 69, 2498.

[23] S. El Fangour, A. Guy, J. P. Vidal, J. C. Rossi, T. Durand, J. Org. Chem. 2005, 70, 989.

[24] E. Pinot, A. Guy, A. Fournial, L. Balas, J. C. Rossi, T. Durand, J. Org. Chem. 2008, 73, 3063.

[25] S. A. Castro-Chavira, A. R. Aguilar-Vazquez, Y. Martinez-Chavez, L. Palma, E. Padilla-Gomez, S. Diaz-Cintra, Nutr. Neurosci. 2016, 19, 329.

[26] J. Collado-González, S. Medina, T. Durand, A. Guy, J.-M. Galano, A. Torrecillas, F. Ferreres, A. Gil-Izquierdo, Food Chem. 2015, 178, 212.

[27] R. Dominguez-Perles, A. Abellan, D. Leon, F. Ferreres, A. Guy, C. Oger, J. M. Galano, T. Durand, A. Gil-Izquierdo, Food Res. Int. 2018, 107, 619.
[28] E. Candráková, N. Polláková, M. Macák, Res. J. Agr. 2011, 43, 25.

[29] M. C. García-García, A. J. Céspedes-López, J. J. Pérez-Parra, P. Lorenzo-Mínguez, 2016, El sistema de producción hortícola protegido de la provincia de Almería (Ed. IFAPA), pp. 169-173.

[30] E. Peksen, A. Peksen, H. Bozoúlu, A. G. L. Mser, Turk. J. Agr. 2004, 28, 363.

[31] V. de Sousa Rocha, F. B. Della Rosa, R. Ruano, M. Zugaib, C. Colli, Clin. Nutr. 2015, 34, 1166.

[32] C. G. Muñoz-Perea, H. Terán, R. G. Allen, J. L. Wroght, D. T. Wetermann, S. P. Singh, Crops Sci. 2006, 46, 2111.

[33] C. Lizana, M. Wentworth, J. P. Martinez, D. Villegas, R. Meneses, E. H. Murchie, C. Pastenes, B. Lercari, P. Vernieri, P. Horton, M. Pinto, J. Exp. Bot. 2006, 57, 685.

[34] E. T. Leermakers, S. K. Darweesh, C. P. Baena, E. M. Moreira, D. Melo van Lent, M. J. Tielemans, T. Muka, A. Vitezova, R. Chowdhury, W. M. Bramer, J. C. Kiefte-de Jong, J. F. Felix, O. H. Franco, Am. J. Clin. Nutr. 2016, 103, 481.

[35] J. M. Martelo-Núñez, B. Ruiz-Nogueira, F. Sau-Sau, Agricultura 1996, 767, 493.

[36] R. Imbusch, M. J. Mueller, Free Radic. Biol. Med. 2000, 28, 720.

[37] D. Leon-Perez, S. Medina, J. Londono-Londono, M. Cano-Lamadrid, A. Carbonell-Barrachina, T. Durand, A. Guy, C. Oger, J. M. Galano, F. Ferreres, C. Jimenez-Cartagena, J. Restrepo-Osorno, A. GilIzquierdo, Food Chem. 2019, 280, 231.

[38] X. Hu, W. Li, Q. Chen, Y. Yang, Plant Signal. Behavior 2009, 4, 696.

[39] K. Dunlop, M. Cedrone, J. F. Staples, T. R. H. Regnault, Nutrients 2015, 7, 1202.

[40] E. Martinez-Force, N. Ruiz-Lopez, R. Garces, Anal. Biochem. 2004, 334, 175.

[41] A. A. H. A. Latef, P. Ahmad, in Legumes Under Environmental Stress: Yield, Improvement and Adaptations (Ed: M. M. A. a. P. Ahmad), John Wiley \& Sons, Ltd., Hoboken, New Jersey, USA 2015. 